\title{
Redesigning of the heating chamber of the Resin Line: A Case Study
}

\author{
Mr. Rohit Sen \\ Lecturer mechanical Engineer, Government polytechnic College, Chittorgarh (Raj.) India.
}

\begin{abstract}
Resin Line is a stone machinery, in which marble \& granite slab reinforcement is done. The reinforcement in done by applying epoxy resin on the slab surface and heat it in a heating chamber number of slab are staked in the heating chamber. Thus the height of the heating chamber is reasonably high in the range of 6-8m.

For maintaining homogeneous temperature in the heating chamber which will produce good quality marble slabs a blower and heater system is used. The hot air from the blower-heater system is supplied to the heating chamber through square cross sectional hollow columns. In all there are six column used in manufacturing of heating chamber. In each column there forty holes of the same diameter. These holes in the first three columns are use to supply the hot air into the heating chamber and the remaining holes of the three columns are used for suction the hot air from the heating chamber.

The practical problem faced by the resin line manufacturing industry is to maintain the homogeneous in a 3.5X2.1X6 $\mathrm{m}$ sized heating chamber. The temperature near the entrance of the hot air into the heating chamber at the bottom was observed to be $45^{\circ} \mathrm{C}$ while it was gradually decreasing and reached up to $40^{\circ} \mathrm{C}$ at the top of the heating chamber. So the qualities of the reinforcement of the marble slabs which are cured at the top of the heating chamber have inferior quality then the slabs at the bottom of the heating chamber. In this situation a very simple but powerful redesigning is done to overcome the above cited problem. In this case study the solution of the problem is obtained by simply increasing the hole diameters gradually from bottom to top keeping total area of the holes same so that blower heater assembly remains same as earlier. In this way the homogenous temperature of $45^{\circ} \mathrm{C}$ has been achieved throughout the heating chamber from top to bottom, which in turn gives assured quality of marble slabs reinforcement.
\end{abstract}

Keywords: R.L.M. (Resin Line machine), T.T. (Tilting trolley), VU (Vacuum Unit), RP (Resin Platform), L (Lift), HC (Heating Chamber), TSP (Touch Screen panel)

\section{Introduction of Resin Line :}

The history of use of marble can be seen in the ancient \& antique sculptures made by ancient emperors. In the era of industrialization many types of marble machinery came into existence but in the period of liberalization and globalization the marble slabs being a natural material faces ironical challenges for its cracks $\&$ defects.

These defects of the marble can be filled by epoxy resin manually \& left for drying \& polymerization in open sunlight. But as soon as the weather changes the sunlight goes dim, and the marble industry faces extreme challenges of on-time delivery to the customers hear large space many workers and lot of time dependency of weather halt the on-time delivery of the marble to the valuable customer.

Thus an idea of the resin line machine comes to the mind of the dignitaries of the B.M. industries and India's first automatic resin line for marble \& granite can into existence at B.M. industries Chittorgarh. It is presently engaged in manufacturing resin line-29. This machine requires (1) Less Space (2) Less Workers (3) Less Time (4) Less running cost (5) Weather independent operation

Main Parts of Resin Line

\section{Working \& Construction}

$\begin{array}{ll}\text { 1) } & \text { Tilting Trolley } \\ \text { 2) } & \text { Vacuum Unit } \\ \text { 3) } & \text { Resin Platform } \\ \text { 4) } & \text { Lift } \\ \text { 5) } & \text { Heating Chamber } \\ \text { 6) } & \text { Touch Screen Panel }\end{array}$




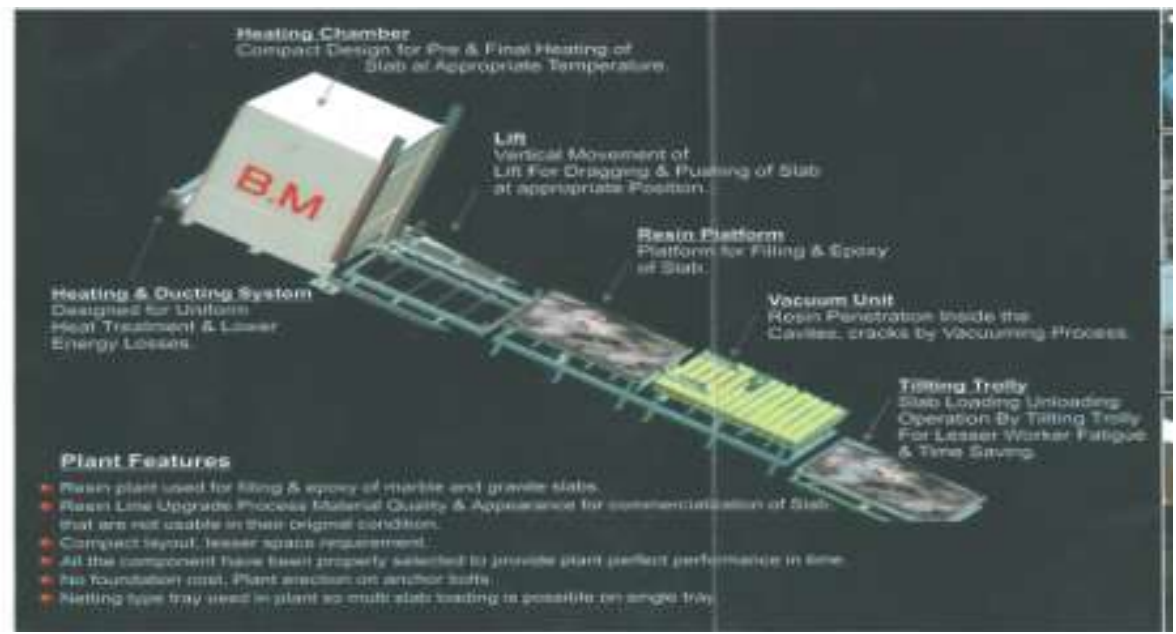

\subsection{Tilting Trolley}

\section{Resin Line}

Automatic loading/unloading procedure of the stone, automatic lifts for the handling of the trays and automatic preparation of the resin are the main points that maximizes the production of the new BM line with only 2 operators for the complete line. All the lines can be customized regarding the dimensions of the trays, the height of the tower and the length according to the available dimensions of the area to be installed.

Slab Loading Unloading Operation By Tilting Trolley For Lesser Worker Fatigue \& Time Saving.

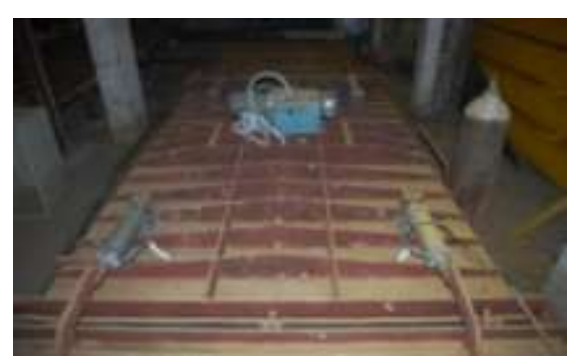

\subsection{Resin Platform}

Flexibility \& adaptability to any stone or type of treatment is the characteristic of the new BM line, making the line appropriate for all the stones. The productivity and the level of automation can be customized to the needs of every application separately, taking in mind the space and the combination of the line with the polishing lines installed. Slabs \& tiles can be treated in the same line. The operation of the line is based on the following steps

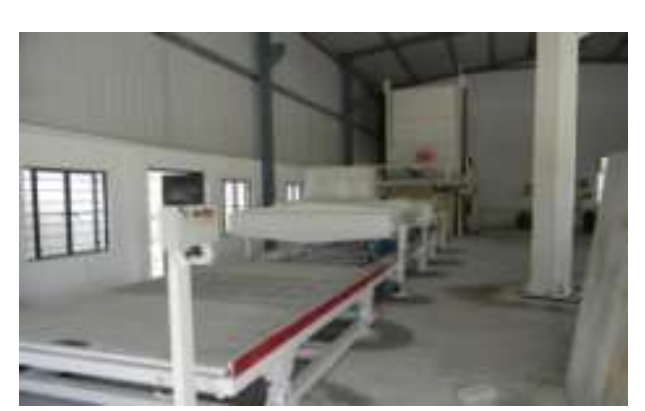

Tilting Platform for Loading \& Unloading of RESIN LINE

\section{2: Vacuum Unit}

The vacuum chamber is forcing the resin to penetrate in the smallest cracks. Double high capacity vacuum pumps achieves almost absolute air vacuum (-0.8 to -0.9 Bar) in less than $30 \mathrm{sec}$ and the slab remains in the vacuum chamber for 60 more seconds. The slab will remain in the chamber between $1^{\prime}$ \& $11 / 2^{\prime}$ min without causing any delay in the operation cycle of the complete line.

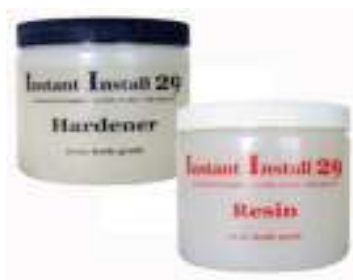

20oz Knife Grade Granite Glue/Epoxy

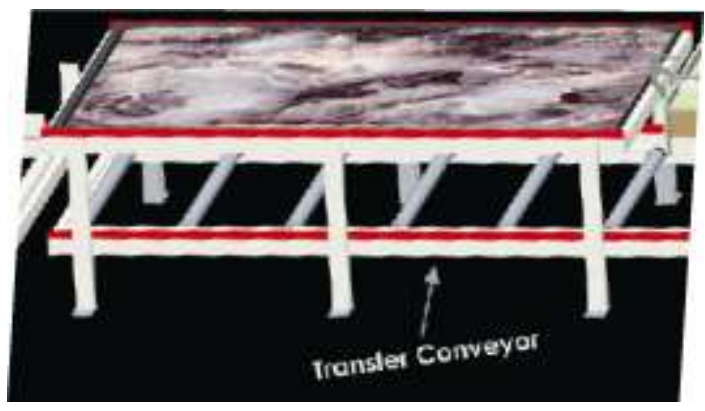

Unlike other epoxies ASII20 Instant Install will not stick to the polished surface on granite, allowing for E-Z clean-up with no more taping off joints. It can be colored to match your granite with a coloring kit, but it does dry water clear! Allstone ASII20 Instant Install is a mercaptan epoxy which has different physical characteristics than other epoxies in that it isn't weather or climate sensitive! It will cure fast in hot or cold temperatures, whether it is humid or arid!

Strongest bond, For lamination \& seams of Granite or Natural Stone, Dries fast even in cold temperatures, Stays flexible, Will not fall, crack, shrink, or stain the stone 

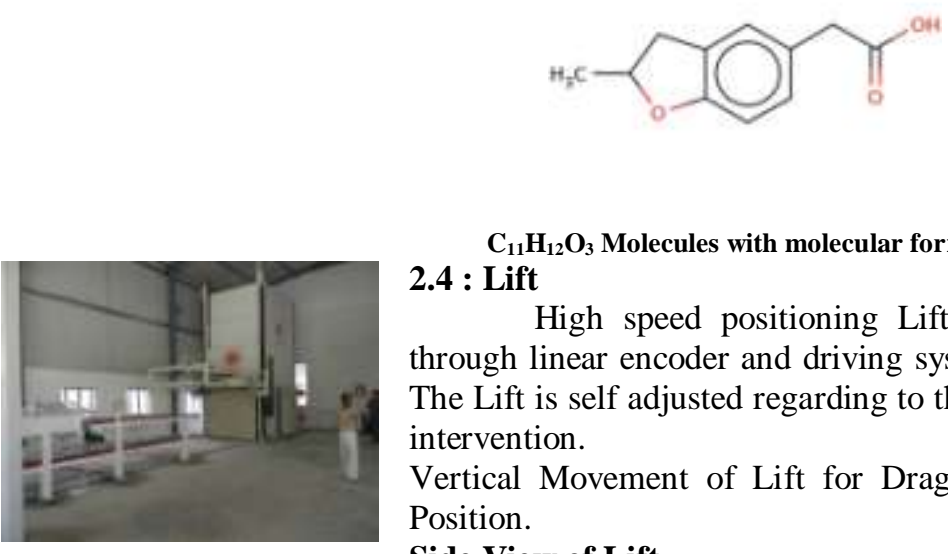

\section{$\mathrm{C}_{11} \mathrm{H}_{12} \mathrm{O}_{3}$ Molecules with molecular formula 2.4 : Lift}

High speed positioning Lift with continues control of its position through linear encoder and driving system of the trays in the heating chamber. The Lift is self adjusted regarding to the trays position eliminating any operator intervention.

Vertical Movement of Lift for Dragging \& Pushing of Slab at appropriate Position.

\section{Side View of Lift}

\section{5 : Heating Chamber}

When the slab reaches the stocking area is completely dry and with the necessary heating energy stored as long as it will remain out of the heating chamber. At the stocking area the steam absorption system removes from the operation area the gases which are produced by the contact of the resin with the hot stone. The optional resin dosing and mixing pump guarantees the correct dosing and mixing of the resin eliminating any operator fault.

The trays of the slabs are constructed in a way to avoid any deformation from the heating and the weight that are carrying. They are constructed in three dimensions 3200x2000mm that can carry slabs of any kind and strips. Compact Design for Pre \& Final Heating of Slab at Appropriate Temperature. Heating \& Ducting System Designed for Uniform Heat Treatment \& Lower Energy Losses.
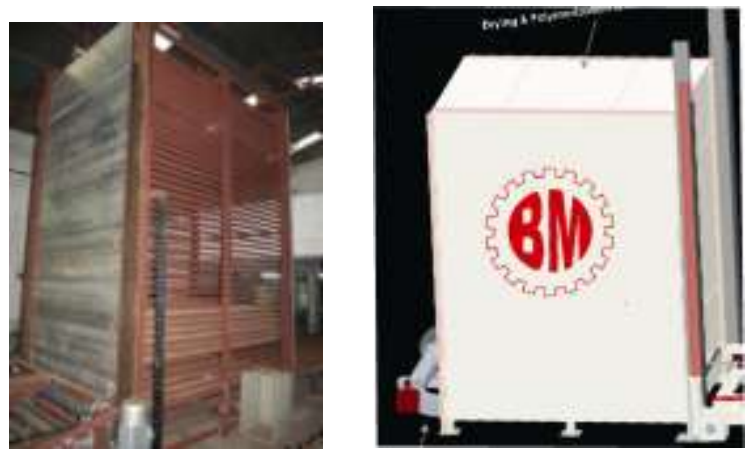

3-D View of Heating Chamber

III. REDESIGNING OF HEATING CHAMBER

3.1

$\mathrm{A}_{\mathrm{t}}($ Total Area $)=120 \mathrm{XA}_{1}$ (Area of single hole)
$\frac{\pi}{4} d^{2}=\frac{\pi}{4}(20)^{2}=314 \mathrm{~mm}^{2}$
$\mathrm{~A}_{\mathrm{t}}=120 \mathrm{XA}_{1}=120 \mathrm{X} 314=37680 \mathrm{~mm}^{2}$

\section{$\mathrm{A}_{1}=$}

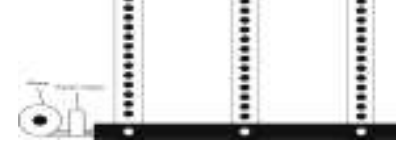

Existing Heating Chamber having normal circular holes of same size

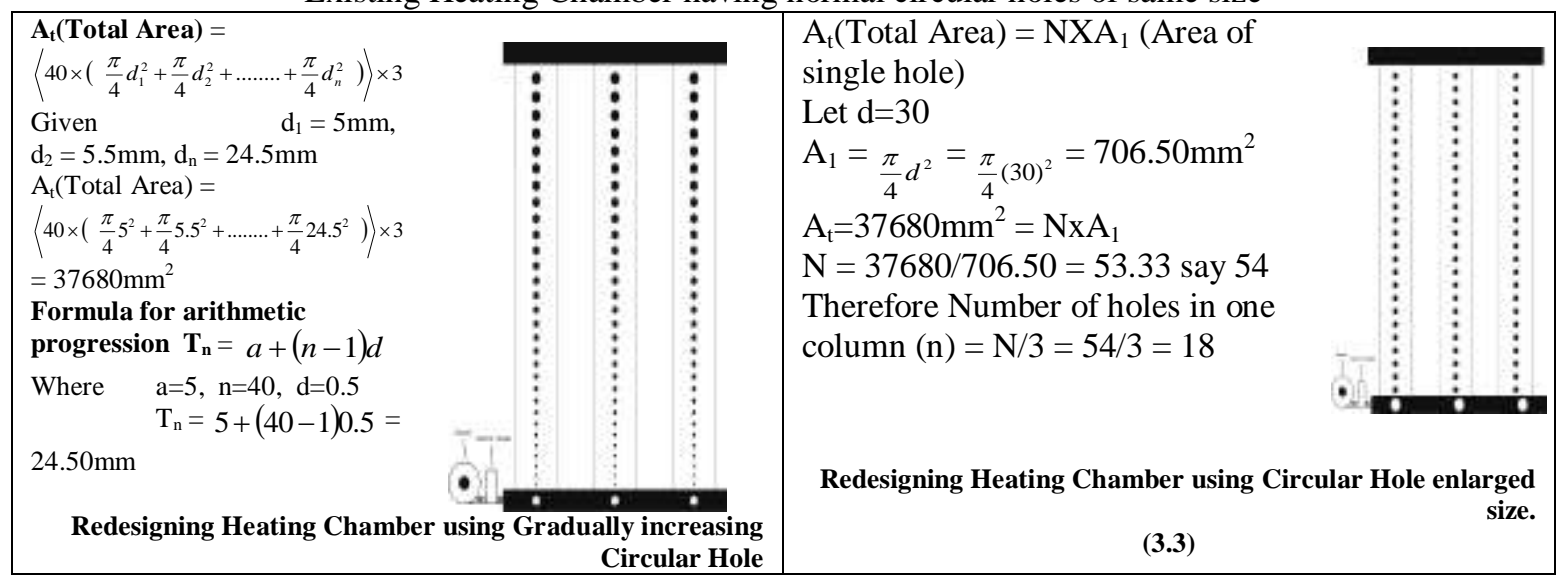




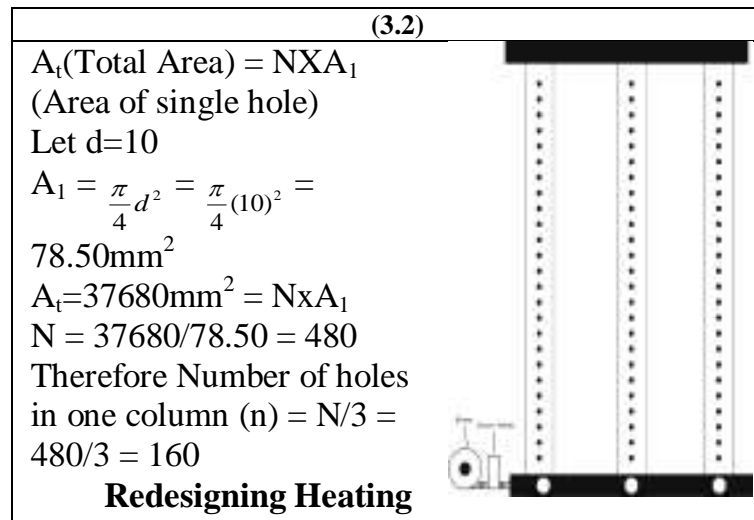

Chamber using Circular Hole of diminished size (3.4)
Redesigning Heating

Chamber using Normal Circular Hole of same size with triple entry of hot ai

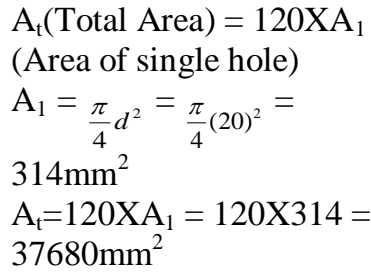

$\mathrm{A}_{\mathrm{t}}($ Total Area $)=120 \mathrm{XA}_{1}$

(Area of single hole)

$\mathrm{A}_{1}=\frac{\pi}{4} d^{2}=\frac{\pi}{4}(20)^{2}=$

$314 \mathrm{~mm}^{2}$

$\mathrm{A}_{\mathrm{t}}=120 \times \mathrm{X}_{1}=120 \times 314=$ $37680 \mathrm{~mm}^{2}$

Redesigning Heating

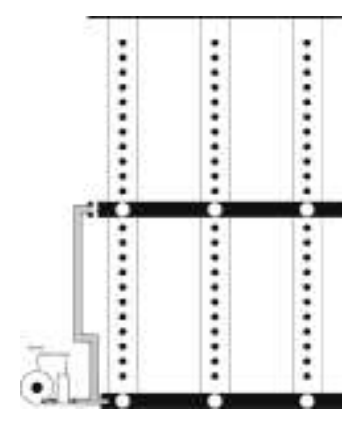

Chamber using Normal Circular Hole of same size with dual entry of hot air size (3.5)

$\mathrm{A}_{\mathrm{t}}($ Total Area $)=120 \mathrm{XA}_{1}$ (Area of single square hole) The side of the square is $17.72 \mathrm{~mm}$

$\mathrm{A}_{1}=a^{2}=(17.72)^{2}=$

$314 \mathrm{~mm}^{2}$

$\mathrm{A}_{\mathrm{t}}=120 \times \mathrm{XA}_{1}=120 \times 314=$ $37680 \mathrm{~mm}^{2}$

Redesigning Heating

Chamber using Square Hole of same size (3.6)

$\mathrm{A}_{\mathrm{t}}($ Total Area $)=120 \mathrm{XA}_{1}$ (Area of Triangle hole $)$

The base of the triangle $b=20 \mathrm{~mm} \& \mathrm{~h}=31.4 \mathrm{~mm}$

$\mathrm{A}_{1}=\frac{1}{2} b \times h=\frac{1}{2} 20 \times 31.4=314 \mathrm{~mm}^{2}$

$\mathrm{A}_{\mathrm{t}}=120 \mathrm{XA}_{1}=120 \times 314=37680 \mathrm{~mm}^{2}$
(3.7)

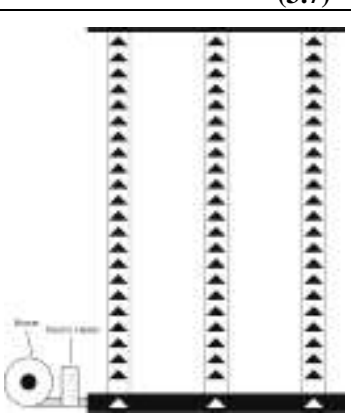

Redesigning Heating Chamber using Triangular Hole of same size (3.8)

IV.

ANALYSIS

4.1 : Observation Table for measurement of temperature, pressure and volume of existing heating chamber of resin line and redesign heating chamber of resin line :-

\begin{tabular}{|c|c|c|c|c|c|c|c|}
\hline \multirow{2}{*}{ S. No } & \multirow{2}{*}{$\begin{array}{c}\text { Hole } \\
\text { number }\end{array}$} & \multicolumn{2}{|c|}{$\begin{array}{c}\text { Temperature } \\
(\mathbf{0} \mathbf{C})\end{array}$} & \multicolumn{2}{c|}{$\begin{array}{c}\text { Pressure } \\
(\mathbf{m m H g})\end{array}$} & \multicolumn{2}{c|}{$\begin{array}{c}\text { Volume } \\
\left(\mathbf{m}^{\mathbf{3}}\right)\end{array}$} \\
\cline { 3 - 8 } & & Existing & Redesigned & Existing & Redesigned & Existing & Redesigned \\
\hline 1 & 1 & 45 & 45 & 20 & 20 & 52.92 & 52.92 \\
\hline 2 & 10 & 44 & 45 & 19 & 20 & 52.92 & 52.92 \\
\hline 3 & 20 & 43 & 45 & 18 & 20 & 52.92 & 52.92 \\
\hline 4 & 30 & 41 & 45 & 17 & 20 & 52.92 & 52.92 \\
\hline 5 & 40 & 40 & 45 & 16 & 20 & 52.92 & 52.92 \\
\hline
\end{tabular}

\subsection{Formulae for Calculations}

* $\quad \mathrm{A}_{\mathrm{t}}$ (Total Area) $=120 \mathrm{XA}_{1}$ (Area of single hole)

$\begin{array}{ll}* & \mathrm{~A}_{1}=\frac{\pi}{4} d^{2} \\ * \quad & \mathrm{~A}_{\mathrm{t}}(\text { Total Area })=\end{array}$

$$
\mathrm{A}_{1}=\frac{\pi}{4} d^{2}
$$

* Therefore Number of holes in one column $(\mathrm{n})=\mathrm{N} / 3$

$* \quad \mathrm{~A}_{\mathrm{t}}($ Total Area $)=120 \mathrm{XA}_{1}$

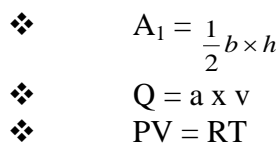

$52 \mid \mathrm{P}$ a g e 
$\left\langle 40 \times\left(\frac{\pi}{4} d_{1}^{2}+\frac{\pi}{4} d_{2}^{2}+\ldots \ldots . .+\frac{\pi}{4} d_{n}^{2}\right)\right\rangle \times 3$

* Formula for arithmetic progression $\mathbf{T}_{\mathbf{n}}=$ $a+(n-1) d$

* $\quad \mathrm{A}_{\mathrm{t}}($ Total Area $)=\mathrm{NXA}_{1}$ (Area of single hole $)$
(Area of single square hole)

$\begin{array}{ll}* & \mathrm{~A}_{1}=a^{2} \\ * & \left.\mathrm{~A}_{\mathrm{t}} \text { (Total Area }\right)=120 \mathrm{XA}_{1}\end{array}$

(Area of Triangle hole)

$$
\begin{aligned}
& \frac{p}{\rho}+\frac{v^{2}}{2 g}+h=C \\
& Q^{*}=k A \frac{\Delta T}{\Delta x} \\
& Q^{*}=h A \Delta T
\end{aligned}
$$

\section{3 : OUTCOME SUMMARY}

\begin{tabular}{|l|l|c|c|c|c|}
\hline \multirow{2}{*}{$\begin{array}{l}\text { S. } \\
\text { No. }\end{array}$} & \multicolumn{1}{|c|}{ Description` } & \multicolumn{4}{|c|}{ Outcome } \\
\cline { 3 - 5 } & $\begin{array}{c}\text { Dimension } \\
(\mathrm{mm})\end{array}$ & $\begin{array}{c}\text { Area of a Single } \\
\text { hole }\left(\mathrm{mm}^{2}\right) \\
\mathrm{A}_{1}\end{array}$ & $\begin{array}{c}\text { Total Area } \\
\left(\mathrm{mm}^{2}\right) \\
\mathrm{A}_{\mathrm{t}}\end{array}$ & $\begin{array}{c}\text { Number of } \\
\text { holes in one } \\
\text { column }\end{array}$ \\
\hline 1. & $\begin{array}{l}\text { Normal Circular Hole of } \\
\text { same size }\end{array}$ & $\mathrm{d}=20$ & 314 & 37680 & 40 \\
\hline 2 & $\begin{array}{l}\text { Gradually increasing } \\
\text { Circular Hole }\end{array}$ & $\begin{array}{c}\mathrm{d}_{1}=5, \mathrm{~d}_{2}=5.5, \\
\mathrm{~d}_{\mathrm{n}}=24.5\end{array}$ & - & 37680 & 40 \\
\hline 3 & $\begin{array}{l}\text { Circular Hole enlarged } \\
\text { size. }\end{array}$ & $\mathrm{d}=30$ & $\mathrm{~A}_{1}=706.5$ & 37680 & 18 \\
\hline 4 & $\begin{array}{l}\text { Circular Hole of } \\
\text { diminished size }\end{array}$ & $\mathrm{d}=10$ & $\mathrm{~A}_{1}=78.5$ & 37680 & 160 \\
\hline 5 & $\begin{array}{l}\text { Normal Circular Hole of } \\
\text { same size with dual entry } \\
\text { of hot air }\end{array}$ & $\mathrm{d}=20$ & 314 & 37680 & 40 \\
\hline 6 & $\begin{array}{l}\text { Normal Circular Hole of } \\
\text { same size with triple } \\
\text { entry of hot air }\end{array}$ & $\mathrm{d}=20$ & 314 & 37680 & 40 \\
\hline 7. & $\begin{array}{l}\text { Square Hole of same size } \\
\text { Th=17.72 }\end{array}$ & 314 & 37680 & 40 \\
\hline 8. & $\begin{array}{l}\text { Triangular Hole of same } \\
\text { size }\end{array}$ & $\mathrm{b}=20$ \\
$\mathrm{~h}=31.4$ & 314 & 37680 & 40 \\
\hline
\end{tabular}

4.4 : Graph

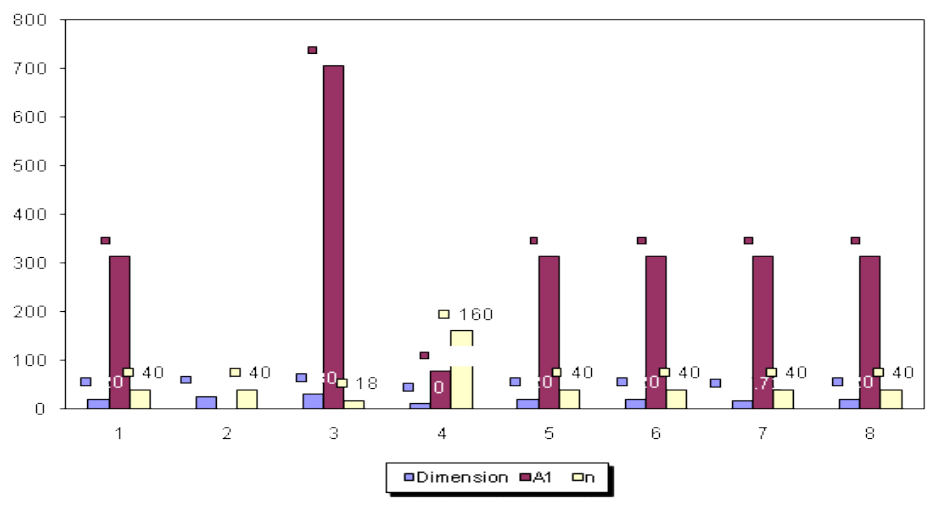

Hole Dimension

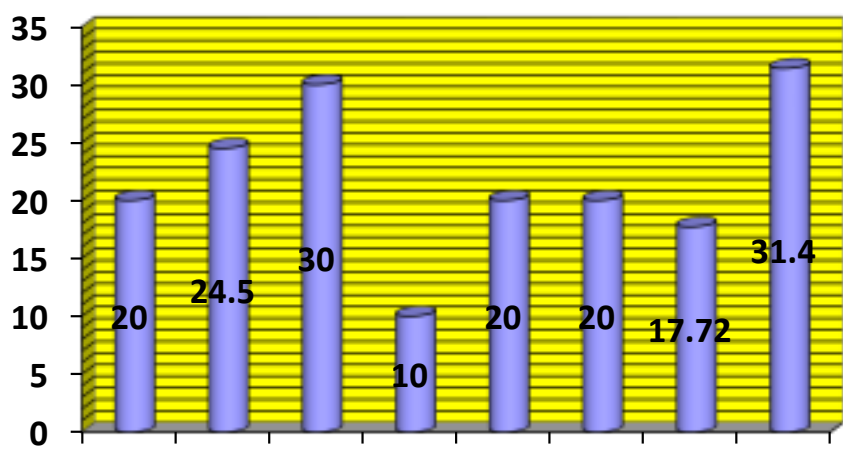

$\begin{array}{llllllll}1 & 2 & 3 & 4 & 5 & 6 & 7 & 8\end{array}$ 


\section{Hole Area}

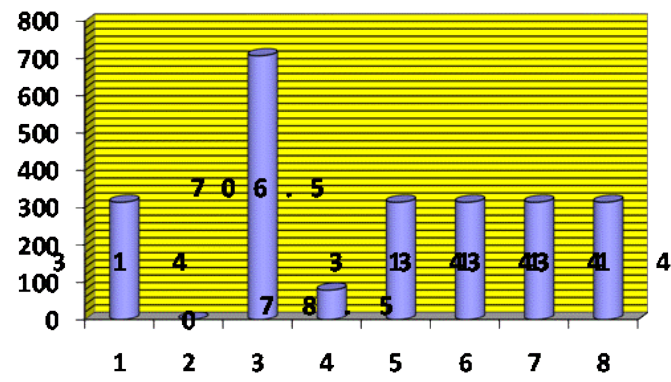

No. of hole in one column

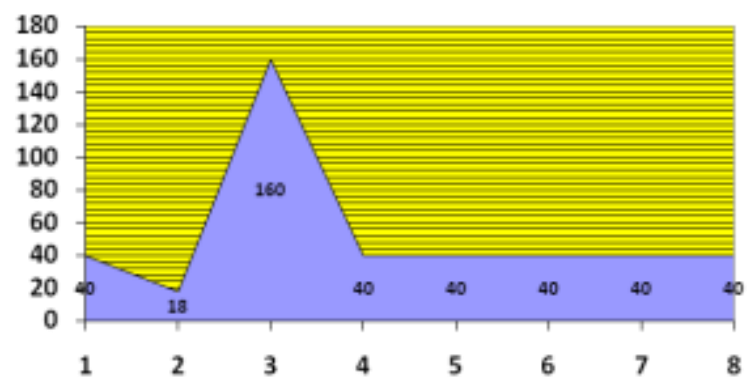

Total Area

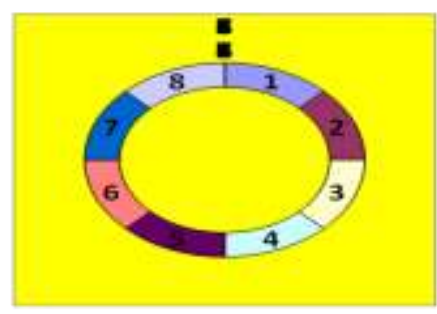

4.5 : Result Analysis

\begin{tabular}{|c|c|c|c|}
\hline & & & \\
\hline $\begin{array}{l}\text { S. } \\
\text { No. }\end{array}$ & Description` & Remarks & Feasibility \\
\hline 1. & Normal Circular Hole of same size & Existing heating chamber & Yes \\
\hline 2. & Gradually increasing Circular Hole & $\begin{array}{l}\text { Redesigned heating chamber practically } \\
\text { accepted by the owner of B.M. Industries }\end{array}$ & Yes \\
\hline 3. & Circular Hole enlarged size. & Non uniform heating & No \\
\hline 4. & Circular Hole of diminished size & Too much holes, weaker column & No \\
\hline 5. & $\begin{array}{l}\text { Normal Circular Hole of same size } \\
\text { with dual entry of hot air }\end{array}$ & $\begin{array}{l}\text { Blower power increases which in turn } \\
\text { increases initial cost of the machine }\end{array}$ & No \\
\hline 6. & $\begin{array}{l}\text { Normal Circular Hole of same size } \\
\text { with triple entry of hot air }\end{array}$ & $\begin{array}{l}\text { Blower power increases which in turn } \\
\text { increases initial cost of the machine }\end{array}$ & No \\
\hline 7. & Square Hole of same size & $\begin{array}{l}\text { At the corner of the square hole stress } \\
\text { concentration, design failure }\end{array}$ & No \\
\hline 8. & Triangular Hole of same size & $\begin{array}{l}\text { At the corner of the triangular hole stress } \\
\text { concentration, design failure }\end{array}$ & No \\
\hline
\end{tabular}




\section{Before}

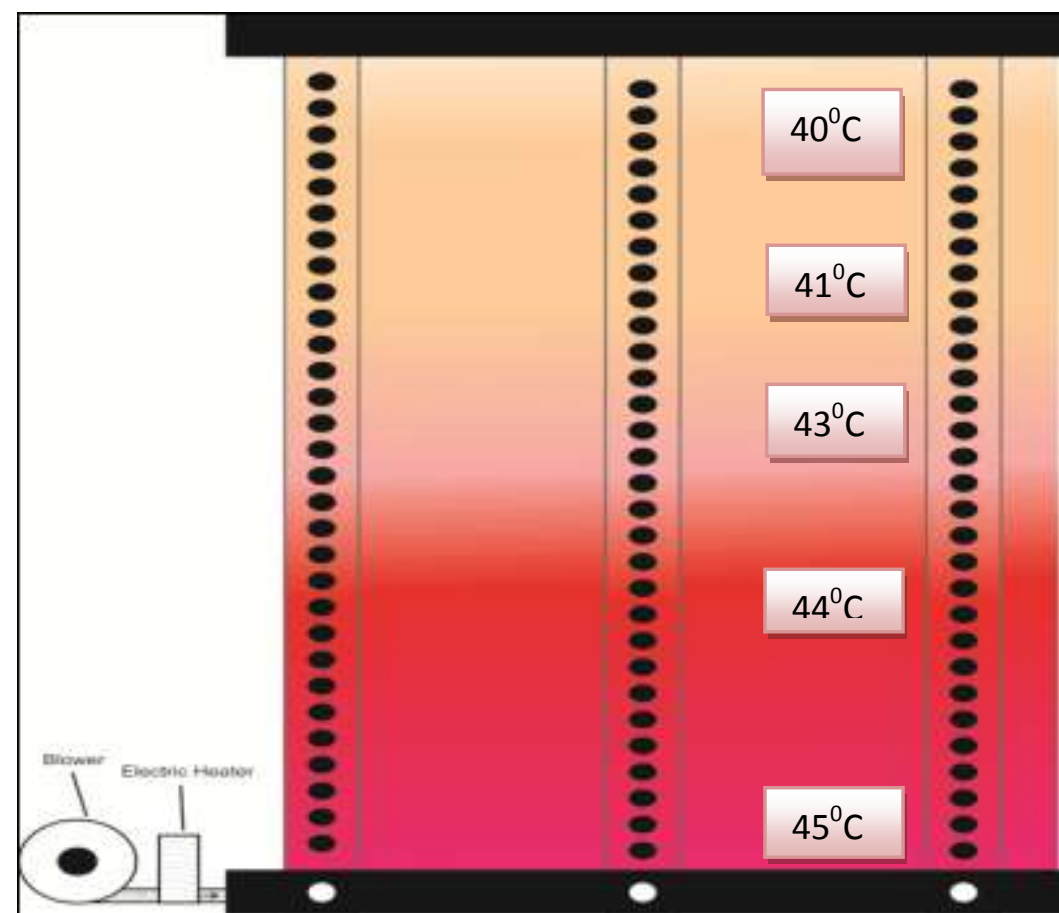

After

Fig. : Variation of Temperature in Heating Chamber

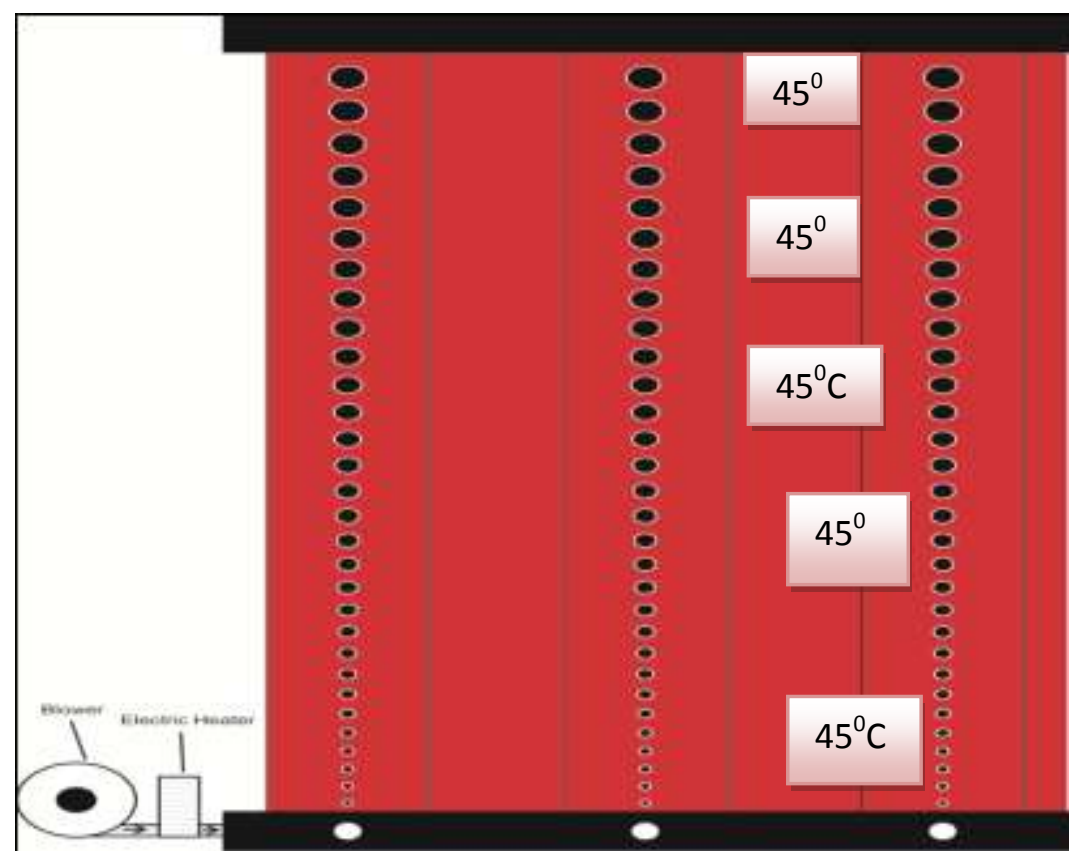

Fig. : Variation of Temperature in Heating Chamber

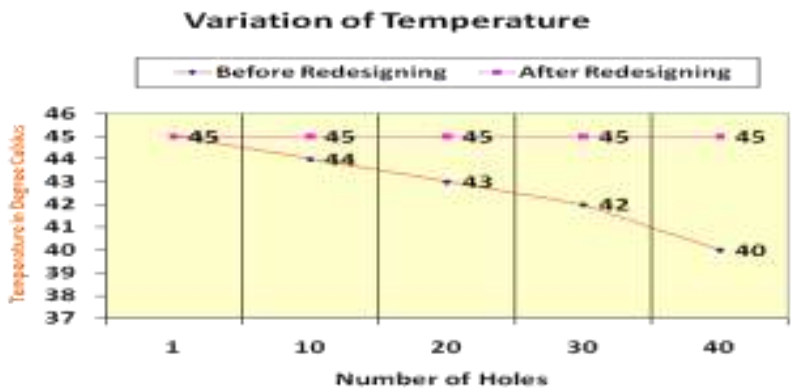




\section{Before}

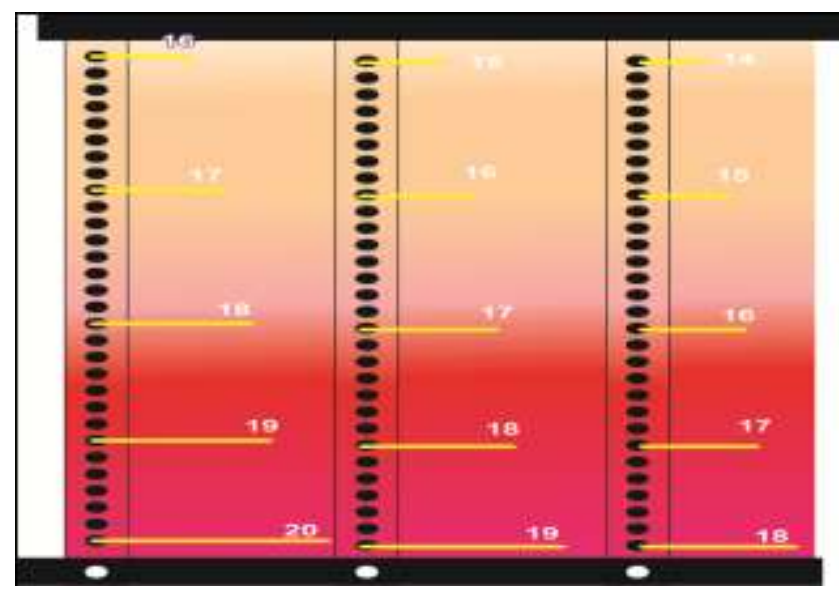

After
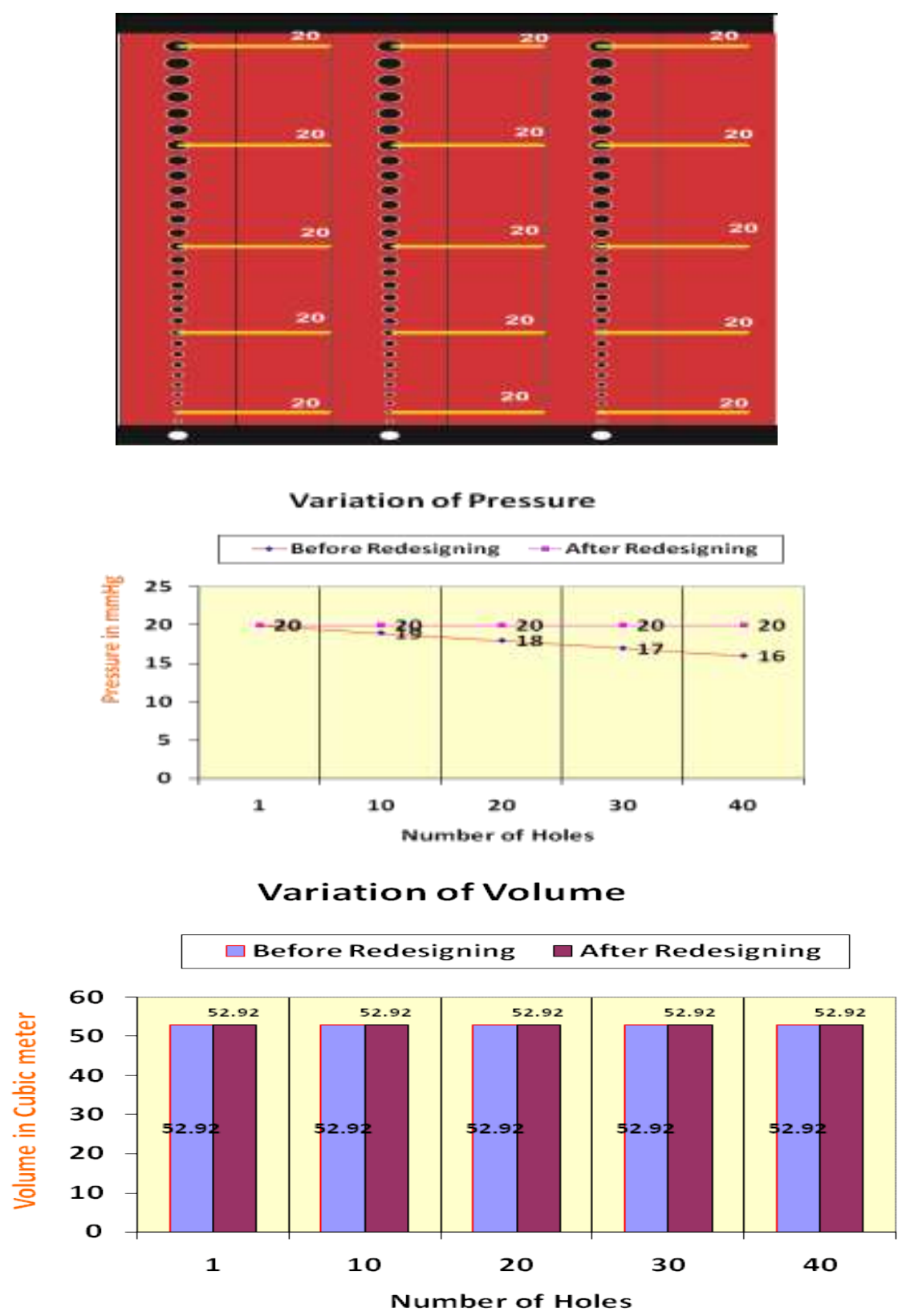


\section{Conclusion:}

The Existing heating chamber of the resin line was not maintained at homogenous temperature of $45^{0} \mathrm{C}$ for slab reinforcement. After redesigning the heating chamber the homogenous temperature of $45^{\circ} \mathrm{C}$ has been achieved just by gradually varying the hole dimensions of the columns of the heating chamber

\section{Acknowledgement:}

This is my privilege to express my deep gratitude towards very few people who supported and encouraged me right from the initiation to completion of my dissertation work First of all I would like to thank Prof D.K. Sharma, Deputy Dean, Faculty of Engineering \& Technology, Mewar University, Chittorgarh \& Head of the Department, Prof. Saurabh Singh Chandrawat, Department of Mechanical Engineering., Faculty of Engineering \& Technology Mewar University, Chittorgarh, who encouraged me time to time for successful completion of our M.Tech. Course Especially I would like to extend my warm thanks to them for their painstaking effort for making things comfortable in the department, without which it would have been a difficult task for me. I would like to express thank, deep from my heart to my Guide Prof. Lalit Yadav, Department of Mechanical Engineering, Faculty of Engineering and Technology, Mewar University, Chittorgarh for having hands of support and love for me during course of study and project work. This work has come to completion due to his support only. I would not forget to use this opportunity to say thank to my Prof. Manvendra Singh \& Prof. Preeti Suryawanshi for their direct and indirect support extended to me. I must not forget to express my gratitude towards few people working with B.M. Industries, Old Industrial Area, Bypass Road, Chittorgarh (Rajasthan). I am specially thankful to Er. Sandeep Maheshwari, President \& Owner, B.M. Industries, for granting me permission for my dissertation work in his premises. I am thankful to Er. Pushkar Sehgal, Executive Manager at B.M. Industries for providing me every help I needed to complete my dissertation work in their company. I would like to thank Sh. M.K. Sharma, Principal, and Sh. B.K. Daiya, Head of the Department (Mechanical Engineering), Government Polytechnic College, Chittorgarh, for cooperating me during my study.

First of all I would like to take blessing of my Gurudev "Om Baba", than my parents Late Dr. Prof. N.L. Sen \& Smt. Chandra Sen, my brother Mr. Rajesh Sen, consultant NABARD, and best wishes of my wife Smt. Saroj Gehlot (Govt. Teacher) and friends \& Seniors \& Colleague Sh. C.S. Tak, Sh. Sanjay Sharma, Sh. D.T. Giyanchandani, Sh. Rajesh Chaudhary, Sh. Rupesh Kalantri, for their love \& support and a special thank to my beloved Daughter \& Son "Sakshi \& Drumil". I thank, also Mr. Ramratan Kumawat (Devri) for typing \& the people who explained, discussed and shared their experiences with me during the course of study.

\section{References:}

[1] Weed, Julie (July 10, 2010). "Factory Efficiency Comes to the Hospital". The New York Times.

[2] M. M. Feldman (1992). "Audit in psychotherapy: the concept of Kaizen". Psychiatric Bulletin. Royal College of Psychiatrists. pp. 334-336.

[3] Imai, Masaaki (1986). Kaizen: The Key to Japan's Competitive Success. New York: Random House.

[4] Europe Japan Centre, Kaizen Strategies for Improving Team Performance, Ed. Michael Colenso, London: Pearson Education Limited, 2000

[5] Tozawa, Bunji; Japan Human Relations Association (1995). The improvement engine: creativity \& innovation through employee involvement: the Kaizen teian system. Productivity Press. p. 34. ISBN 978-1-56327-010-9. Retrieved 6 February 2010.

[6] www.bmindustries.com 